\title{
Penile anthropometry in adolescents and adults systemic lupus erythematosus
}

\author{
Ana P. Vecchi ${ }^{* *}$, Eduardo F. Borba ${ }^{1}$, Eloísa Bonfá ${ }^{1}$, Marcelo Cocuzza² ${ }^{2}$ Patrícia Pieri ${ }^{3}$, Chong A Kim³ ${ }^{3}$ Clovis A. Silva ${ }^{1,3}$ \\ From 18th Pediatric Rheumatology European Society (PReS) Congress \\ Bruges, Belgium. 14-18 September 2011
}

\begin{abstract}
Aim
The objective of this study was to evaluate penile anthropometry in systemic lupus erythematosus (SLE) patients and controls.
\end{abstract}

\section{Methods}

Twenty-five consecutive SLE patients were assessed by urological examination, sexual function, testicular ultrasound, hormones, sperm analysis, genetic analysis, clinical features and treatment. The control group included 25 healthy age-matched healthy men.

\section{Results}

SLE patients had a lower median penis length and circumference $[8(7.5-10)$ vs. $10(8-13) \mathrm{cm}, \mathrm{p}=0.0001 ; 8(7-$ $10)$ vs. $10(7-11) \mathrm{cm}, \mathrm{p}=0.001$; respectively], lower median testicular volume by right and left Prader [15(10-25) vs. $20(12-25) \mathrm{ml}, \mathrm{p}=0.003 ; 15(10-25)$ vs. $20(12-25) \mathrm{ml}$, $\mathrm{p}=0.006$; respectively], higher median of FSH [5.8(2.1$25)$ vs. 3.3(1.9-9) IU/l, $p=0.002$ ] and lower morning total testosterone levels $(28 \%$ vs. $0 \%, \mathrm{p}=0.009)$ compared to controls. In spite of that, erectile dysfunction was not observed in patients or controls. Analyses of lupus patients revealed that the median penis circumference was lower in patients with disease onset before first ejaculation compared to those that began after first ejaculation [7.8(7-10) vs. 9.0(7.5-10) cm, p=0.026]. No differences were observed in the median penile anthropometry regarding sexual dysfunction $(\mathrm{p}=0.610)$, lower total testosterone levels $(\mathrm{p}=0.662)$, oligo/azoospermia $(\mathrm{p}=0.705)$, SLEDAI $\geq 4(\mathrm{p}=0.562)$, SLICC/ACR Damage Index $\geq 1 \quad(\mathrm{p}=0.478)$, prednisone cumulative dose $(\mathrm{p}=0.789)$ and intravenous cyclophosphamide therapy $(\mathrm{p}=0.754)$. Klinefelter's syndrome $(46 \mathrm{XY} / 47 \mathrm{XXY})$ was

${ }^{1}$ Rheumatology Division, Faculdade de Medicina da Universidade de São Paulo, São Paulo - Brazil

Full list of author information is available at the end of the article diagnosed in one (4\%) SLE patient with decreased penile size whereas Y-chromosomal microdelections was absent in all of them.

\section{Conclusion}

We have identified reduced penile dimensions in SLE patients with no deleterious effect in erectile function. Disease onset before first ejaculation seems to affect penis development in pre-pubertal lupus.

\section{Author details}

'Rheumatology Division, Faculdade de Medicina da Universidade de São Paulo, São Paulo - Brazil. Urology Department, Faculdade de Medicina da Universidade de São Paulo, São Paulo - Brazil. ${ }^{3}$ Pediatric Rheumatology Unit, Faculdade de Medicina da Universidade de São Paulo, São Paulo - Brazil.

Published: 14 September 2011

doi:10.1186/1546-0096-9-S1-P256

Cite this article as: Vecchi et al:: Penile anthropometry in adolescents and adults systemic lupus erythematosus. Pediatric Rheumatology 20119 (Suppl 1):P256.

Submit your next manuscript to BioMed Central and take full advantage of:

- Convenient online submission

- Thorough peer review

- No space constraints or color figure charges

- Immediate publication on acceptance

- Inclusion in PubMed, CAS, Scopus and Google Scholar

- Research which is freely available for redistribution

\section{Biomed Central}

(c) 2011 Vecchi et al; licensee BioMed Central Ltd. This is an open access article distributed under the terms of the Creative Commons Attribution License (http://creativecommons.org/licenses/by/2.0), which permits unrestricted use, distribution, and reproduction in any medium, provided the original work is properly cited. 